\title{
GAMBARAN PROGRAM PENGENDALIAN MALARIA DI KOTA LUBUK LINGGAU
}

\author{
Tri Bayu Purnama ${ }^{1}$ \\ ${ }^{1}$ Departemen Epidemiologi dan Biostatistik, Fakultas Kesehatan Masyarakat, \\ Universitas Islam Negeri Sumatera Utara, Medan
}

\begin{abstract}
Indonesia is one of the countries that are endemic to malaria with the prevalence of malaria cases in 2010 at 22.9 per 1000 population. A solution to reduce malaria cases in Indonesia is to develop a malaria elimination program. So based on this issue, the aim of this study was to find out an overview of malaria control programs in LubukLinggau City. The malaria control program in LubukLinggau City had not yet a specific goal in the malaria control program but the program has a technical strategy and activities in the malaria control program. The malaria control program activities carried out are treatment using chloroquine, distribution of insecticide, larvacide bed nets, spraying and laboratory tests. The malaria control program had not yet reached the target that can be seen from AMI and API in 2013 but also had not yet reached the target for LubukLinggau City. Then the problems in the malaria control program are the absence of malaria control programs, no malaria cases treated with $\mathrm{ACT}$, as many as $4.2 \%$ of malaria cases were laboratory confirmed and program evaluation only referred to outcome indicators.
\end{abstract}

Keyword : Malaria, Policy, Lubuk Linggau

\begin{abstract}
ABSTRAK
Indonesia adalah salah satu negara yang endemis malaria dengan prevalensi kasus malaria tahun 2010 sebesar 22.9 per 1000 penduduk. Salah satu cara untuk menurunkan kasus malaria di Indonesia adalah dengan menyusun program eliminasi malaria. Sehingga berdasarkan hal tersebut penelitian ini bertujuan untuk mengetahui gambaran program pengendalian malaria di Kota Lubuk Linggau. Program pengendalian malaria di Kota Lubuk Linggau belum memiliki tujuan dalam program pengendalian malaria secara tersendiri tetapi program tersebut memiliki strategi teknis dan kegiatan dalam program pengendalian malaria. Kegiatan program pengendalian malaria yang dilakukan adalah pengobatan dengan menggunakan klorokuin, pembagian kelambu berinsektisida, larvasida, penyemprotan dan pemeriksaan laboratorium. Program pengendalian malaria belum mencapai target yang dapat dilihat dari AMI dan API tahun 2013 belum mencapai target rencana pembangunan jangka panjang dan menengah Kota Lubuk Linggau tahun 2013. Kemudian permasalahan dalam program pengendalian malaria adalah belum adanya tujuan program pengendalian malaria, tidak adanya kasus malaria yang diobati dengan ACT, sebanyak 4,2\% kasus malaria yang dikonfirmasi laboratorium dan evaluasi program yang hanya mengacu pada indikator outcome.

Kata kunci : Malaria, Kebijakan, LubukLinggau
\end{abstract}




\section{PENDAHULUAN}

Malaria adalah penyakit menular yang disebabkan oleh parasit protozoa genus Plasmodium yang menjadi masalah kesehatan masyarakat. World Health Organization (WHO) tahun 2011 mengestimasikan bahwa insiden malaria di dunia mencapai 215 juta kasus dan diantara yang terinfeksi parasit Plasmodium sekitar 655 ribu (WHO, 2011). Riset Kesehatan Dasar (Riskesdas) tahun 2013 melaporkan bahwa dari 33 Provinsi di Indonesia terdapat 15 provinsi mempunyai prevalensi malaria diatas angka nasional dimana sebagian besar berada di Indonesia Timur. Kemudian angka kesakitan malaria positif di Indonesia tahun 2013 sebesar 1,9\% dan prevalensi kasus malaria positif tahun 2013 sebesar 6\%. Oleh karena itu, perlu menyusun sebuah program pemberantasan dan pengendalian kasus malaria untuk mencapai target MDG's (Millennium Development Goals).

Pemberantasan malaria di Indonesia merupakan salah satu bagian dari penyelesaian program pemberantasan penyakit menular bersumber binatang. Belum selesainya masalah ini karena disebabkan dari berbagai aspek seperti permasalahan lingkungan, perilaku dan pelayanan kesehatan di Indonesia sehingga belum dapat ditangani dengan tuntas. Hal ini ditandai dengan masih sering terjadi kejadian luar biasa malaria di Indonesia dan beberapa wilayah Indonesia dinyatakan sebagai wilayah endemis malaria. Oleh karena itu salah upaya pemberantasan malaria dapat dilakukan melalui program pengendalian malaria.

Program pengendalian malaria yang dilakukan oleh pemerintah melalui berbagai kegiatan seperti pengobatan kasus malaria, pembagian kelambu berinsektisida, surveilans kasus malaria, pengendalian nyamuk dan survei malaria. Kegiatan ini disusun untuk mengendalikan malaria yang ada di masyarakat dengan kegiatan pengobatan dan pencegahan. Program ini diharapkan mampu menurunkan kasus malaria yang ada di suatu wilayah.

Program pengendalian malaria yang bertujuan untuk menurunkan kasus malaria telah lama dilakukan namun hasilnya masih belum sesuai dengan yang diharapkan. Kendala umum yang dijumpai dalam pemberantasan malaria ini antara lain kendala tekhnis dan manajerial program. Salah satu contoh kendala teknis di lapangan adalah penyemprotan insektisida nyamuk ke dinding rumah belum sesuai dengan bionomik vektornya sehingga tindakan yang dilakukan tidak efektif dan efisien. Serta salah satu kendala manajerial program adalah perencanaan program pengendalian malaria yang tidak berdasarkan evidence based.

Perencanaan program masih terkendala dalam pengendalian dan manajerial program di lapangan yang tidak berdasarkan evidence based. Hal ini dapat mengakibatkan kegiatan yang direncanakan tidak dapat menyelesaikan masalah malaria. Perencanaan program yang sesuai dengan kejadian/fakta di lapangan akan membantu dalam menurunkan kejadian malaria di daerah endemik secara efektif dan efisien. Salah satu daerah endemik malaria di Indonesia adalah Kota Lubuk Linggau, Provinsi Sumatera Selatan.

Kota Lubuk Linggau merupakan salah satu kota yang berada di Provinsi Sumatera Selatan. Angka kesakitan malaria di kota ini dari tahun 2008 sampai 2013 adalah 13,05 \%o, 17,88\%o (Kemenkes, 2013), 13,58 \%o, 13,13 \%o 10,21 \%o dan 10,00 \%o (Dinkes Lubuk Linggau, 2013). Annual Paracite Incidence (API) di Kota Lubuk Linggau di tahun 2013 sebesar 1,58 per 1000 penduduk (Dinkes Kota Lubuk Linggau, 2013) padahal standar yang telah ditetapkan oleh Dinas Kesehatan Provinsi Sumatera Selatan sebesar < 1,00 per 1000 penduduk (Dinkes Provinsi Sumsel, 2013). 
Kasus malaria di Kota Lubuk Linggau yang berada diatas rata-rata Provinsi Sumatera Selatan membuat kota tersebut untuk menyusun program pengendalian malaria. Program ini bertujuan untuk menurunkan kasus malaria dibawah nilai rata-rata provinsi dan MDGs. Sehingga diperlukan perencanaan program pengendalian malaria di Dinas Kesehatan Kota Lubuk Linggau yang nantinya kegiatan pengendalian malaria dapat dilakukan oleh seluruh Puskesmas yang ada di Kota Lubuk Linggau. Tujuan umum dari penelitian ini adalah mengetahui gambaran program pengendalian malaria di Dinas Kesehatan Kota Lubuk Linggau.

\section{METODOLOGI PENELITIAN}

Metode penelitian yang digunakan dalam penelitian ini adalah kualitatif eksploratif dengan informan kepala seksi program penanggulangan penyakit, penanggung jawab program malaria dinas kesehatan dan puskesmas endemis malaria dan kepala bidang pengendalian penyakit dan penyehatan lingkungan. Metode pengumpulan data yang digunakan dalam penelitian ini adalah wawancara mendalam, observasi lapangan dan telaah dokumen yang berkaitan dengan malaria.

Variabel yang diukur dalam penelitian ini adalah tujuan program pengendalian malaria, strategi teknis program pengendalian malaria, pokok kegiatan program pengendalian malaria, teknik perencanaan program pengendalian malaria, teknik pelaksanaan program pengendalian malaria, indikator kinerja program pengendalian malaria, teknik evaluasi program pengendalian malaria, cara mengukur keberhasilan program pengendalian malaria danpermasalahan dalam pelaksanaan program pengendalian malaria

\section{HASIL}

Diagnosa malaria harus terkonfirmasi mikroskop / uji reaksi cepat (Rapid Diagnostic Test / RDT)

Kegiatan ini dilakukan dengan tujuan untuk menghentikan jumlah kasus malaria klinis yang datang berobat ke Puskesmas. Semua puskesmas yang ada di Kota Lubuk Linggau sudah dibagikan RDT oleh Dinas Kesehatan. Hal ini membantu dalam mendiagnosis jenis Plasmodium yang ada pada kasus yang butuh penegakkan diagnosis laboratorium. Akan tetapi RDT yang ada belum digunakan oleh petugas yang ada di Puskesmas karena petugas Puskesmas lebih terbiasa menggunakan mikroskop dan adanya keyakinan dari petugas bahwa penggunaan mikroskop lebih valid karena darah yang di ambil berdasarkan darah vena sedangkan RDT menggunakan darah perifer. Dari 8 Puskesmas yang ada di Kota Lubuk Linggau, baru 5 puskesmas yang bisa mengoperasionalkan laboratorium untuk pengecekan Plasmodium pada kelompok kasus malaria. Hal ini dikarenakan beberapa Puskesmas masih kekurangan sumber daya untuk melakukan pemeriksaan. Selain menggunakan mikroskop, alat lain yang digunakan untuk pemeriksaan parasit malaria adalah rapid diagnostic test (RDT).

Pengobatan dengan Artemisinin Combination Therapy (ACT) dan tidak menggunakan obat klorokuin di Puskesmas

Pengobatan Malaria yang ada di Puskesmas terdiri dari pengobatan radikal dan pengobatan klinis. Pengobatan radikal terdiri dari pengobatan ACT dan Non ACT. Di Puskesmas Perumnas dan Puskesmas Simpang Periuk, kelompok yang diberikan obat non ACT adalah kelompok kasus malaria klinis yang dilakukan pemeriksaan laboratorium. Jenis obat yang digunakan pada kelompok non ACT radikal adalah klorokuin. Penggunaan klorokuin sudah dilarang oleh pemerintah pusat karena 
resistensi obat terhadap Plasmodium (Kemenkes, 2007). Pihak Puskesmas tetap memberikan klorokuin karena mereka hanya menggunakan obat yang dikirim dari Dinas Kesehatan ke Puskesmas. Kemudian pada kelompok malaria klinis yang tidak diperiksa laboratorium diberikan pengobatan klinis non ACT.

Pencegahan penularan malaria dengan pendistribusian kelambu (Long Lasting Insecticidal Net/LLiN), penyemprotan (Indoor Residual Spraying/IRS), repellent dan larvasida

Pendistribusian kelambu berasal dari hibah Dinas Kesehatan Provinsi Sumatera Selatan ke Dinas Kesehatan Kota Lubuk Linggau yang kemudian didistribusikan ke Puskesmas yang ada di Kota Lubuk Linggau.

Tabel 1. Distribusi Kelambu Ke Puskesmas

\begin{tabular}{clc}
\multicolumn{3}{c}{ di Kota Lubuk Linggau } \\
\hline No & Puskesmas & $\begin{array}{c}\text { Jumlah } \\
\text { Kelambu } \\
\text { (buah) }\end{array}$ \\
\hline 1 & Taba & 0 \\
2 & Perumnas & 68 \\
3 & Sidorejo & 0 \\
4 & Megang & 17 \\
5 & Simpang & 21 \\
& Periuk & 0 \\
6 & Petanang & 0 \\
7 & Citra Medika & 0 \\
8 & Sumber Waras & 106 \\
& Jumlah &
\end{tabular}

Berdasarkan tabel diatas, tidak semua puskesmas dibagikan kelambu karena hanya beberapa puskesmas yang endemik malaria. Oleh karena itu pembagian kelambu hanya difokuskan pada 3 puskesmas yang memiliki kasus malaria terbanyak. Selanjutnya setelah kelambu tersebut didistribusikan ke puskesmas, tahap selanjutnya adalah didistribusikan ke wilayah kerja puskesmas yang endemis malaria. Salah satu Puskesmas yang mendapatkan kelambu adalah puskesmas Perumnas.

Selama tahun 2013 Puskesmas Perumnas dibagikan 30 kelambu untuk disebar ke 11 wilayah kerja Puskesmas. Pembagian yang dilakukan dengan bantuan dari bagian surveilans Puskesmas untuk memetakan 5 wilayah endemis malaria dengan berdasarkan laporan kunjungan pasien yang berobat dan jumlah pasien dengan wilayah paling banyak menderita malaria. 5 wilayah endemis tersebut mendapatkan kelambu berinsektisida paling banyak dari wilayah kerja lainnya. Berikut tabel distribusi kelambu berinsektisida di Puskesmas Perumnas.

Tabel 2. Wilayah Kerja Puskesmas Perumnas Yang Mendapatkan

\begin{tabular}{clc}
\multicolumn{2}{c}{ Kelambu Berinsektisida (LLiN) } & $\begin{array}{c}\text { Jumlah } \\
\text { Kelambu } \\
\text { (Buah) }\end{array}$ \\
\hline No & \multicolumn{1}{c}{ Kelurahan } & 5 \\
1 & Kayuara & 6 \\
2 & Bandung Ujung & 1 \\
3 & Bandung Kiri & 6 \\
4 & Sukajadi & 6 \\
5 & Lubuk Aman & 4 \\
6 & Muara Enim & 1 \\
7 & Lubuk Tanjung & 1 \\
8 & Tanjung Indah & 30 \\
& Jumlah &
\end{tabular}

Selain IRS dan LLiN, Program pengendalian malaria selanjutnya adalah dengan memberikan larvasida pada tempat perkembangan nyamuk Anopheles. Pemberian larvasida seperti briket ini di letakkan di dalam air seperti sawah, selokan dan tempat perkembangan nyamuk Anopheles lainnya. Pemberian larvasida ini di berikan oleh Dinas Kesehatan Provinsi 
Sumatera Selatan melalui hibah kepada Dinas Kesehatan Kota Lubuk Linggau.

Memperkuat kelurahan siaga dengan pengaktifan kader malaria di tiap kelurahan

Kegiatan memperkuat kelurahan siaga belum maksimal. Hal ini dikarenakan kader malaria belum ada dan masih menjadi tugas dari kader posyandu yang ada disetiap wilayah kelurahan. Kemudian peran kelurahan dalam program pengendalian malaria masih belum terintegrasi dengan kegiatan yang dilakukan oleh tenaga kesehatan.

Monitoring dan evaluasi penemuan kasus dan pengobatan kasus yang berobat di Puskesmas

Monitoring dan evaluasi dilakukan dengan melihat hasil laporan bulanan yang dikirim oleh Puskesmas ke Dinas Kesehatan di tiap bulannya. Dari hasil laporan yang masuk ke Seksi P2 dan Seksi Surveilans, akan dilihat jumlah kasus yang terjadi di tiap bulannya. Kemudian laporan tersebut akan dijadikan bahan masukkan dalam perencanaan program pengendalian malaria seperti kegiatan pembagian kelambu, insektisida, sistem kewaspadaan dini malaria dan pemeriksaan laboratorium (Kemenkes, 2006). Data yang digunakan dalam kegiatan monitoring dan evaluasi adalah data mengenai kesakitan, kematian, PR, SPR, data vektor seperti MBR, jenis vektor, bionomik vektor, status kerentanan vektor dan data mengenai lingkungan (Kemenkes, 2007).

Tabel 3. Indikator Kinerja Dinas Kesehatan Kota Lubuklinggau yang Mengacu pada Tujuan dan Sasaran Rencana Pembangunan Jangka Menengah Daerah Kota Lubuk Linggau 2013-2017

\begin{tabular}{|c|c|c|c|c|c|c|c|c|c|}
\hline \multirow[t]{2}{*}{ No } & \multicolumn{2}{|c|}{$\begin{array}{c}\text { Indikator kinerja } \\
\text { Sasaran }\end{array}$} & \multirow[t]{2}{*}{$\begin{array}{c}\text { Kondisi } \\
\text { Kinerja } \\
\text { pada } \\
\text { awal } \\
\text { periode } \\
\text { RPJMD } \\
\mathbf{2 0 1 3} \\
\end{array}$} & \multicolumn{5}{|c|}{ Target Capaian Setiap Tahun } & \multirow[t]{2}{*}{$\begin{array}{c}\text { Kondisi } \\
\text { Kinerja } \\
\text { pada } \\
\text { akhir } \\
\text { periode } \\
\text { RPJMD }\end{array}$} \\
\hline & & & & 2013 & 2014 & 2015 & 2016 & 2017 & \\
\hline 23 & $\begin{array}{l}\text { Angka } \\
\text { Kasus } \\
\text { Malaria } \\
\text { (Annual } \\
\text { Paracite } \\
\text { Index- } \\
\text { API) }\end{array}$ & $\begin{array}{l}\text { per } 1.000 \\
\text { penduduk }\end{array}$ & 1,76 & 3,5 & 3 & 2,5 & 2 & 1,5 & 1 \\
\hline 24 & $\begin{array}{l}\text { Angka } \\
\text { Kejadian } \\
\text { Malaria } \\
\text { per } 1.000 \\
\text { penduduk } \\
\text { (AMI) }\end{array}$ & $\begin{array}{l}\text { per } 1.000 \\
\text { penduduk }\end{array}$ & 10,0 & 7 & 6,5 & 6 & 5,5 & 5 & 4,5 \\
\hline 25 & $\begin{array}{l}\text { Tingkat } \\
\text { Kematian } \\
\text { Akibat } \\
\text { Malaria }\end{array}$ & $\begin{array}{l}\text { per } 1.000 \\
\text { penduduk }\end{array}$ & $\mathrm{n} / \mathrm{a}$ & 1 & 0,9 & 0,8 & 0,7 & 0,6 & 0,5 \\
\hline
\end{tabular}


Menjalin kemitraan dengan Puskesmas dan Dinas Kesehatan Provinsi Sumatera Selatan

Kegiatan dalam menjalin kemitraan dengan Puskesmas dan Dinas Kesehatan Provinsi Sumatera Selatan dalam alokasi barang dan informasi yang berkaitan dengan malaria. Jejaring kerja dalam program pengendalian malaria terbagi menjadi 2 bagian yaitu program malaria dan surveilans malaria. Program malaria memiliki jejaring kerja seperti Dinas Pendidikan, Kantor Kementerian Agama Kota/Kabupaten, Bappeda, Dinas Kehutanan, Dinas Pertanian dan Kantor Lingkungan Hidup. Indikator kinerja program pengendalian malaria berdasarkan indikator kinerja Dinas Kesehatan Kota Lubuk Linggau adalah seperti Tabel 3.

Berdasarkan Tabel 3, diketahui bahwa API kasus malaria di Kota Lubuk Linggau berada dibawah target capaian ditahun 2013 tetapi berdasarkan indikator kinerja sasaran AMI, kasus malaria masih menjadi masalah kesehatan masyarakat di Kota Lubuk Linggau tahun 2013. Keadaan indikator AMI yang berada pada 10 per 1000 penduduk, maka ada beberapa puskesmas yang masih diatas rata-rata AMI tersebut.

\section{PEMBAHASAN}

Tujuan program pengendalian malaria di Kota Lubuk Linggau masih mengacu pada tujuan program pengendalian malaria Kementerian Kesehatan RI. Hal ini dikarenakan malaria masih belum menjadi prioritas masalah kesehatan yang ada di Kota Lubuk Linggau. Penentuan proritas masalah malaria ini berdasarkan dari indikator API dimana malaria akan menjadi prioritas masalah jika kota ini adalah daerah endemis malaria tinggi (API $>5 \%$ ). Tujuan program eliminasi malaria menurut Keputusan Menteri Kesehatan Republik
Indonesia

Nomor 293/MENKES/SK/IV/2009 tentang Eliminasi Malaria di Indonesia adalah terwujudnya masyarakat yang hidup sehat, yang terbebas dari penularan malaria secara bertahap sampai tahun 2030 dengan menurunnya kasus Malaria (API) dari 2 menjadi 1 per 1.000 penduduk.

Upaya konkrit yang dapat dilakukan oleh Pemerintah Kota Lubuk Linggau dalam menunjukkan komitmen yang kuat untuk bebas malaria di tahun 2020 adalah dengan mengeluarkan peraturan walikota tentang tata cara pelaksanaan eliminasi malaria. Salah satu daerah yang melakukan upaya seperti ini adalah Provinsi Bali dengan dikeluarkannya Peraturan Gubernur No. 10 tahun 2010 tentang tata cara pelaksanaan eliminasi malaria di Provinsi Bali dan Peraturan Bupati Karangasem No. 2 tahun 2010 tentang eliminasi Malaria di Kabupaten Karangasem (Roosihermiatie, 2012).Pelaksanaan kegiatan pokok program pengendalian malaria dapat diketahui dengan keadaan program pengendalian malaria berdasarkan hasil rencana kerja operasional program pengendalian malaria.

RDT sudah disebarkan ke seluruh Puskesmas Kota Lubuk Linggau. Salah satu puskesmas yang menggunakan RDT dalam pemeriksaan laboratorium Puskesmas Perumnas Kota Lubuk Linggau memiliki kendala dalam RDT nya. RDT di Puskesmas ini tidak bisa digunakan dalam pemeriksaan plasmodium pada penderita karena pada strip tersebut sudah terdapat warna ungu muda di bagian darahnya sehingga garis yang digunakan sebagai salah satu penentuan indikator Plasmodium tidak bisa digunakan sehingga tidak berfungsi dengan baik.Kemudian sistem pelaporan yang digunakan oleh Dinas Kesehatan mencantumkan pemeriksaan malaria klinis 
dengan mikroskop dan RDT. Tetapi dalam formulir laporan bulanan penemuan kasus malaria tidak di cantumkan jenis metode yang dilakukan Puskesmas dalam pemeriksaan Plasmodium. Sehingga Dinas Kesehatan mengkategorikan setiap pemeriksaan laboratorium plasmodium pada malaria dengan metode mikroskop. Oleh karena itu, laporan penggunaan RDT ke Dinas Kesehatan Provinsi menjadi 0 kasus.

Pemeriksaan parasit dengan gold standart adalah dengan menggunakan mikroskop. Penggunaan mikroskop dapat dilihat dengan secara langsung pada sediaan darah yang diambil pada kasus yang dicurigai malaria. Pemeriksaan menggunakan pewarnaan flourescensi dengan acridine orange yang memberikan warna spesifik terhadap eritrosit yang terinfeksi Plasmodium (Wempi, 2011). Walaupun pemeriksaan dengan menggunakan mikroskop ini merupakan gold standart, kekurangan dari cara ini adalah tidak dapat menghitung jumlah parasit, tidak dapat membedakan antar spesies dan harganya yang relatif mahal (Wempi, 2011 dan Kemenkes, 2007).

Obat diberikan sesuai dengan gejala klinis yang ada pada tiap-tiap kasus tertentu sehingga dimungkinkan setiap kasus memiliki obat yang berbeda padahal samasama menjadi kasus malaria klinis. Pengendalian malaria selalu mengalami perkembangan dan contohnya adalah penggunaan klorokuin yang terbukti resisten terhadap Plasmodium. Oleh karena itu pengobatan malaria tidak dilakukan dengan pengobatan tunggal tetapi sekarang sudah dikembangkan dengan menggunakan pengobatan kombinasi yaitu ACT (Kemenkes, 2007, danArsin, 2012). Artemisinin merupakan obat antimalaria kelompok seskuiterpen lakton yang bersifat skizontosida darah untuk $P$. falciparum dan $P$. vivax. Obat ini berkembang dari obat tradisional Cina untuk penderita demam yang dibuat dari ekstrak tumbuhan Artemesia annua L (qinghao) yang sudah dipakai sejak ribuan tahun lalu dan ditemukan peneliti Cina tahun 1971 (Tjitra, 2005).

LLIN adalah kelambu yang mengandung insektisida yang dicampurkan atau dibalutkan ke benangnya dan memiliki daya tahan terhadap berkali-kali pencucian. Kelambu tersebut harus tetap memiliki aktivitas biologik sebagai proteksi personal sepanjang masa pemakaiannya. Satu di antara dua jenis LLIN yang disetujui oleh WHO, yaitu Olyset yang berbahan polietilen dan mengandung insektisida permetrin (WHO, 2011).Tujuan dari penggunaan kelambu adalah melindungi pemakai kelambu dari gigitan nyamuk dan untuk mencegah penularan malaria (Laipeny, 2011). Tempat yang tepat diberikannya kelambu ini adalah tempat dengan endemis tinggi, terjadi KLB atau tempat yang penyemprotan sudah tidak efektif lagi (Arsin, 2012). Efektifitas penggunaan kelambu ini tergantung dari penularan terjadi di dalam rumah, kebiasaan menggigit vektor malaria di dalam rumah dengan puncak gigitan setelah jam 22.00, penduduk tidak tidur sampai larut malam (nonton TV, aktifitas lainnya dalam rumah), dan tidak berada di luar rumah malam hari serta masyarakat mau menggunakan kelambu (Nurbayani, 2013).

Selain pembagian kelambu berinsektisida, IRS dilakukan ketika masyarakat menginginkan dilakukan penyemprotan di lingkungan wilayah kelurahan masing-masing. Alur permintaan penyemprotan dilakukan dengan permintaan warga ke kelurahannya lalu melaporkan ke Puskesmas atau ke Dinas Kesehatan Kota Lubuk Linggau. IRS dilakukan dengan menyemprotkan cairan ke dinding rumah warga. Tetapi masyarakat sering untuk menolak untuk dilakukan penyemprotan karena cairan yang 
disemprotkan ke dinding yang sudah di cat akan menimbulkan bekas di dinding tersebut sehingga warga akan menolak untuk di lakukan penyemprotan IRS. IRS adalah penempelan/penyemprotan racun serangga ke dinding rumah dengan dosis tertentu. Permukaan dinding rumah yang telah disemprotkan racun tersebut dapat memutus mata rantai penularan nyamuk Anopheles (Hamusse dkk, 2012 dalam Rahman, 2013).

Peran sumber daya manusia dalam penggerakan active case detection menjadi cukup penting karena pelaksanaan program pengendalian malaria dengan pemberdayaan masyarakat akan dapat berkesinambungan (Capah, 2008). Kegiatan yang dapat dilakukan dalam peningkatan sumber daya manusia adalah re-orientasi program menuju tahap eliminasi disampaikan kepada petugas kesehatan pemerintah maupun swasta yang terlibat dalam eliminasi malaria agar mereka memahami tujuan eliminasi dan tugas yang harus dilaksanakan, pelatihan/refreshing tenaga mikroskopis Puskesmas dan rumah sakit pemerintah maupun unit pelayanan kesehatan swasta serta menjaga kualitas pemeriksaan sediaan darah, pelatihan tenaga pengelola malaria dalam bidang teknis dan manajemen, sosialisasi dan pelatihan tata laksana penderita (Kemenkes, 2009).

Kegiatan pengendalian malaria yang dilakukan secara lintas sektor cukup berpengaruh dalam penyebaran malaria. Peningkatan jumlah kasus malaria diakibatkan dari perubahan lingkungan yang tidak berwawasan kesehatan serta tingginya mobilitas penduduk yang masuk dari daerah endemis malaria ke daerah non endemis malaria (Roosihermiatie, 2011).

\section{KESIMPULAN}

Tujuan program pengendalian malaria di Dinas Kesehatan Kota Lubuk Linggau belum dibuat. Tujuan program pengendalian malaria masih mengacu pada tujuan program eliminasi malaria nasional.Strategi teknis dari program pengendalian malaria di Dinas Kesehatan Kota Lubuk Linggau tahun 2013 adalah penemuan dini dan pengobatan penderita, meningkatkan akses pelayanan yang berkualitas mulai dari tingkat Puskesmas, Puskesmas Pembantu dan Puskesmas Kelurahan, pemberdayaan dan pengorganisasian masyarakat, meningkatkan komunikasi, informasi dan edukasi, Menggalang kemitraan, meningkatkan sistem surveilans, meningkatkan sistem monitoring dan evaluasi serta meningkatkan kualitas sumber daya manusia.Pokok kegiatan dalam pengendalian malaria di Dinas Kesehatan Kota Lubuk Linggau adalah diagnosa malaria terkonfirmasi mikroskop/uji reaksi cepat di Puskesmas, pengobatan dengan klorokuin, pencegahan penularan malaria dengan distribusi kelambu (LLiN), Penyemprotan (IRS), Reppelent dan Larvasida.

\section{DAFTAR PUSTAKA}

Arsin, Andi Arsunan. (2012). Malaria di Indonesia Tinjauan Aspek Epidemiologi. Penerbit Masagena Press. Makasar

Capah, T. (2008). Kajian Perencanaan Manajemen Lingkungan Dalam Program Pengendalian Malaria Di Kabupaten Asmat Tahun 2008. Semarang: Program Pasca Sarjana Universitas Diponegoro.

Dinas Kesehatan Provinsi Palembang (2011). Profil Kesehatan Provinsi Sumatera Selatan 2010.

Dinas Kesehatan Kota Lubuk Linggau (2014). Laporan Bulanan Kasus Malara Kota Lubuk Linggau Tahun 2010-2012.

Kemenkes. (2007). Pedoman Teknis Pemeriksaan Parasit Malaria. Direktorat Pengendalian Penyakit Bersumber Binatang, Dirjen PP dan PL, Kementerian Kesehatan RI. 
Kemenkes. (2009). Keputusan Menteri Kesehatan Republik Indonesia Nomor 293/MENKES/SK/IV/2009 Tentang Eliminasi Malaria. Jakarta: Kementerian Kesehatan.

Kemenkes. (2013). Insiden Malaria di Kota Lubuk Linggau Tahun 2007-2008. Dipetik May 12, 2013, dari Data Base Kesehatan:

http://www.bankdata.depkes.go.id/propi nsi/public/report/createtablepti.

Nurbayani, Lara. (2013). Faktor Risiko Kejadian Malaria Di Wilayah Kerja Puskesmas Mayong I Kabupaten Jepara. Jurnal Kesehatan Masyarakat 2013, Volume 2, Nomor 1, Januari 2013.

Laipeny, Ludia Fin. (2011). Hubungan Tindakan Pencegahan Masyarakat Dengan Kejadian Malaria Di Wilayah Kerja Puskesmas Waihoka Kecamatan Sirimau Kota Ambon Tahun 2011. Jurnal MKMI, Vol 9 No.1, Januari 2013, hal 7-14.
Rahman, Andi Ira Angraeny dkk. (2013). Efek Pelaksanaan Indoor Residual Spraying (IRS) Terhadap Penurunan Monthly Parasite Incidence (MOPI) Di Desa Paria Kecamatan Poleang Tengah Kabupaten Bombana Tahun 2013. Jurnal Masyarakat Epidemiologi IndonesiaVol. 1, No. 3, Januari-Juni 2013: 182-192.

Roosihermiatie, B., \& Rukmini. (2012). Analisis Implementasi Kebijakan Eliminasi Malaria Di Provinsi Bali. Buletin Penelitian Sistem Kesehatan Vol. 15 No. 2 , 143-153.

Tjitra, Emilia. (2005). Pengobatan Malaria Dengan Kombinasi Artemisinin. Bul. Penel. Kesehatan, Vol. 33, No. 2,2005: 53-61.

WHO. (2011). World Malaria Report 2011 Fact Sheet. Global Malaria Programme.

Wempi, I Gede. (2011). Analisis Pemeriksaan Laboratorium Pada Penderita Malaria. BALABA Vol. 8, No. 02, Des 2012 : 58-59 